\title{
Teachers Feedback in Teaching Writing of Narrative Texts to the Eight Grade Students
}

\author{
Yuni Ansari Rambe \\ Department of English Applied \\ Linguistic \\ Universitas Negeri Medan \\ Medan, Indonesia \\ Yz.ansari.rambe@gmail.com
}

\author{
Syahron lubis. \\ Universitas Negeri Medan \\ Medan, Indonesia
}

\begin{abstract}
Writing skills is considered the most difficult skill. The students usually face many difficulties in exploring the ideas or even finding the appropriate words to what they want to write. In this research, the researcher focuses on giving teachers written feedback in teaching writing narrative texts to the eight graders of SMP Amiruddiniyah Rantau prapat . Written feedback is taken to provide an interaction between students writing and the teacher. In this process a teacher read the students work and responds to it through some written comments. The subjects of the study were the students of Eight grades . There were forty students, twenty male and twenty female students. This study is descriptive qualitative. The instruments that are used by the researcher are observation checklist, field notes, and students writtenworks. the researcher collected the data from three observations. The first observation, the writing task was given to check the understanding of the students in writing narrative text,but the teacher didnt give feedback. In the second and third observations feedback were given. In the second observation, the writing task was done in groups. Meanwhile in the third observation, it was done individually. The researcher analyzed the students written works that had been given written feedback from the teacher
\end{abstract}

Keywords: Teacher Written Feedback, Writing, Narrative text, Students Written Work

\section{INTRODUCTION}

There are four language skills in teaching English as the needs of students; they are; reading, listening, speaking, and writing. One of the important skills is writing. Writing is a process of putting thoughts, ideas, opinions, experiences event and history. Writing is one of language skills by which students can express their ideas in written form. It means they have to be able to write correct sentences and arrange them into a good paragraph. Writing is a process to obtain the product which is affected by several elements such as vocabulary, grammar, organization, spelling, and punctuation. Furthermore, students need English writing teacher who can help them.
One of the most important role in transferring and teaching English language at the school is teacher's. How she or he tells and works is going to impact the students' knowledge of English. Moreover, the purpose of teaching writing is to develop students' writing skills so that students can write English effectively and efficiently. The teacher as well-educated expert gives feedback to their students intentionally to reflect and make improvement to their students' writing. It is true that there is no such thing good teaching without good feedback (Nicol, 2009). Writing should be practiced and learned gradually so that the students master it well. It takes time to be able to write. It needs some proper guidance and sustained practices (Cantony and Harvey, 1987:81). From the statement above, it is clear that students need sustained practices to write a composition, an essay, or even a paragraph. Learning to write well takes practice and writing needs written feedback. Providing feedback in a second language is integral to develop students' writing skills (Herrera, 2011:245).

According to the results of the study conducted by the researchers above, teachers' feedback has an influence on the students writing ability. Therefore, if the teachers didn't give the students' any feedback in the writing process, they wouldn't know and understand about their mistakes in the writing. It makes them keep on committing the same errors for the next time. Thus they will not be interested in writing. Unfortunately,they will not be able to master English or at least write in English.

Those difficulties are also faced by the students in SMP Amiruddiniyah Rantau Prapat. When the researcher did teaching practice there, she found many students said that English is difficult to be understood, especially in writing a narrative text. Then the researcher asked about the reason why they could not enjoy writing. They said that they didn't know how to write correctly based on the elements of writing, language features, and generic structures

Based on the explanation given in the background, the problems of the study is formulated in the following question

1. How the teacher gives a written feedback to the students'written work?

Based on the statment of the problem above, the purpose of this study To elucidate the feedback are given to the students written work 


\section{LITERATURE REVIEW}

The term feedback is used to describe the information that comes back from readers to the writer. Carmer et al (2008) explains that feedback is greater in face-to-face conversation than it is in written communication. They also see that the slower the feedback, the more useful it is to plan in advance what a written work is likely to mean to its readers. Feedback is an important component of the formative assessment process. Formative assessment gives information to teachers and students about how students are doing relative to classroom learning goals. Brookhart (2008). The best way to improve one's writing skills is to write, receive feedback from an instructor, revise based on the feedback, and then repeat the whole process as often as possible. Unfortunately, this puts an enormous 5 load on the classroom teacher, who is faced with reading and providing feedback for perhaps 30 essays or more every time a topic is assigned. As a result, teachers are not able to give writing assignments as often as they would wish. Burstein (2004:27)

\section{Narrative Text}

By paragraph, the narrative paragraph tells the story of an event, providing the relevant details of when and where the event occurred as well as who was included and what transpired. The paragraph describes either an actual event or a fictional one that the writer creates.

Narratives are stories about person or a group of people overcoming problems (Joyce \& Feez, 2000). They also explain that narratives show how people react to experiences, explore social and cultural values and entertain the audience.Itaims to entertain, to get and retain the attention of the reader or listener of the story (Derewianka, 1990; Joyce \&Feez, 2000; Anderson \& Anderson, 2003; Gerot \& Wignell, 1994).

According Anderson \& Joyce, (2004), Joyce and Feez (2000) propose that the structures of narratives includes orientation, complication, evaluation, resolution, and coda. Furthermore, like any other texts that have their own linguistic features; Joyce \&Feez (2000) also suggest that narratives have some linguistic features as listed below:

a. Specific often individual participants with defined identities. Major participants are human, or sometimes animal with human characteristic.

b. Mainly use action verb (material processes), that describe what happens.

c. Many narratives also use thinking verbs (mental processes) that gives us information about what participants are thinking or feeling, such as wondered, remembered, thought, felt, disliked.

d. Normally use past tense

e. Dialogue often includes and uses a number of saying verb (verbal process) such as said, asked, and replied. The tense may change to the present or future in the dialogue.
Sometimes these saying verbs also indicate how something is said.

f. Descriptive language is use to enhance and develop the story by creating image in the reader's mind.

g. Can be written in the first person (I, We) or third person (he, she, they)

As mentioned previously, narratives have several processes that exist in the story to draw the character's experience

\section{METHODOLOGY}

This research applied a descriptive qualitative research design. Design is defined as a researcher's plan of how to proceed (Bogdan and Biglen, 1992:58). It aims to present a detailed, contextual picture of a particular phenomenon (Heigham \& Croker, 2009:71)

The reason why the researcher chooses descriptive qualitative is because the researcher wants to observe the teacher and the students' activities in the classroom. How they get involved in the teaching and learning process in writing a narrative text when teacher's feedback is given narrative text in the class. In this case, from the information she identified how the teacher gives written feedback and how the students write composition of a narrative text. Finally, the researcher makes a report of every detail of the teaching learning process in the classroom by describing what the researcher has got from the data observation, since everything had a potential power of becoming the clue to open a more comprehensible understanding on what happened in the classroom. One English teacher who gives written feedback and X111 class of SMP Amiruddiniyah Rantau Prapat were the participants of this study. The researcher takes this grade one of the language skills that must be achieved is a writing skill. In addition, a writing narrative text is taught in this grade. X111 class is taken randomly. It consists of 40 students; 20 maleand 20 female students. The Class is heterogeneous, which means that the academic levels vary from the highest to the lowest. Because of its being heterogeneous, the students' compositions vary too. This study used observation checklist, field notes, and students' written works to collect the data. The data of this study was the results of theobservation about how the teacher gives feedback in teaching writing narrative texts during the teaching and learning process. The second data was the students' writings which measured by ESLcomposition profile.

Firstly, the data obtained from observation checklist and field note were analyzed according to the fact and the researcher's interpretation. The researcher analyzed the data got from the observation naturally based on the phenomenon that had happened in the writing class during the implementation of teacher's feedback in teaching writing a narrative text in order to get the whole view of classroom activities. Secondly, the researcher analyzed the students written works that had been given written feedback from the teacher. In order to describe how the students write a 
narrative text based on the elements of writing. The students' written works were analyzed by ESL Composition Profile. Those were described whether its categories were very good, good, fair, and poor. It was used to know how the student's writing ability after giving teacher's feedback the terms of elements of writing. Those are: content organization, vocabulary, language use and mechanics.

\section{DISCUSSION}

The students' writings were analyzed by using Jacob's ESL Composition Profile. There were 5 items analyzed. They are content, organization, vocabulary, language use and mechanic. Each item was categorized in four levels; very good,

good, fair and poor. In the first meeting, the writing task was given to check the students' understanding in report texts, but at this meeting the teacher's feedback had not been given to the student's written work, the writing task was given to check the understanding of students in writing narrative texts. Thus, the researcher only discussed the result of the students' writing a narrative text in the second and third meetings where the teacher's written feedback had been given to the students' written work. In the second meeting, it was done in a group. Meanwhile, in the last meeting, it was done individually

In terms of content, there were many students who getting very good level. From the students' task in the second and third meeting, writing narrative text after giving teacher's feedback in pairs: there were 16 students got very good level, 9 students got good level, 5 students got fair level, and 2 got poor level. While in the third meeting, where the teacher's feedback was given again and the students wrote individually, the result of their writing; was as follows 19 students got very good level, 12 students got good level, 2 students got fair level, and no one got poorlevel. In terms of organization, the students' writing ability in organizing paragraph improved; The students understood more about fluent expression, ideas clearly stated or supported, well-organized in clear stage of narrative (orientation, complication, and resolution). Those can be seen from the results of the students' writing ability progress. In the second meeting where the students wrote narrative texts in pairs, there were 12 students who got very good level, 10 students got good level, 10 students got fair level and no one got poor level. While in the third meeting where the teacher's feedback was given again and the students wrote individually, there were 16 students who got very good level, 15 students got good level, 2 students got fair level, and no one got poor level. In terms of vocabulary, most of the students could use the appropriate words. It could be seen from the result of the students' writings in the second and third meetings. In the second meeting where the students wrote narrative texts in pairs, there were 8students who got very good level, 14 students got good level, 8 students got fair level and 2 students got poor level. While in the third meeting where the students wrote narrative texts individually, there were 12 students who got very good level, 16 students got good level, 5 students got fair level, and none got poor level. In language use, there were a few students who got very good level. The students got still confused to use appropriate action verb in constructing simple present sentences. It could be seen from the result of the students' writings in the second and third meetings. In the second meeting where the students wrote narrative texts in pairs, there were 3 students who got very good level, 6 students got good level, 15 students got fair level and 9 students got poor level. While in the third meeting where the students wrote narrative texts individually, there were 11 students who got very good level, 15 students got good level, 8 students got fair level, and none got poor level. In the terms of mechanics, it could be seen from the result of the students' writings in the second and third meetings. In the second meeting where the students wrote narrative texts in pairs, there were 12 students who got very good level, 8 students got good level, 10 students got fair level and 2 students got poor level. While in the third meeting where the students wrote narrative texts individually, there were 14 students who got very good level, 15 students got good level, 4 students got fair level, and none got poor level.Based on the result of the students' narrative writing task, the researcher concluded that by giving teacher's written feedback could make progress in composing narrative texts.

\section{FINDINGS}

In this study the teacher used three meetings. In the first meeting, the teacher tried review the narrative text. She didn't give the written feedback because she wanted to check the understanding of students about a narrative text. As a result, in the first meeting, the researcher knew that that most of the students did not have a good understanding about narrative text. They were still confused to use the verbs that used in narrative text. The students didn't know how to change the present tense forms into past tense forms. Thus, in the first meeting, she concerned to review the explanation of narrative text; the generic structure and language features. To make the students understand about narrative texts, the teacher asked the students to identify a narrative text based on the generic structures and language features of a narrative text. After that, she asked them to write a narrative text based on three topics that she had given. And the last, she gave the reflection by asking questions related tothe learning material.In the second meeting, the teacher asked the students to write a narrative text in pairs, after that she gave them written feedback. The teacher gave the feedback based on the student's mistakes. The topic in the second meeting was fairy tale story in narrative texts such as: Cinderella, Sleeping beauty, Snow white and etc. If the students' had finished writing narrative 
texts, the teacher asked them to present their work in front of the class. Their presentations were correct but some of the groups still had difficulties to the tenses of a narrative text. The teacher understood their problem so she wrote the formula of past tense on the whiteboard. She also gave brief explanation about it. If the students did not know the past form of certain verbs, she suggested them to look up it in a dictionary. All of the groups had presented their works, after that the teacher asked them to rewrite their composition based on the teacher's feedback. They were very active and interested in doing writing test because the result of feedback could help them in writing a narrative text. Then, the teacher analyzed their writing a narrative text based on content, organization, vocabulary, language use, and mechanics. She used Jacob ESL Composition Profile Scoring to analyze the students' composition narrativetexts. In the third meeting, the teacher reviewed the material in the previous meetings. After that, she asked the students to write a narrative text individually. The teacher gave the interesting topic to the students that were the students' experiences in the past. The teacher explained the differences between a recount and a narrative text. The students looked enthusiastic because they had known their story. That is a good point to increase the students' motivation in writing a narrative text. After finishing their writing, the teacher gave the written feedback on the students' written work one by one clearly. So, the students could understand the written feedback easily. The students rewrote their composition based on the result of teacher written feedback. In this meeting, they looked understandable and did not find any confusion. They can follow the teacher's written feedback very well. They were very understood and motivated because the teacher's written feedback could make them enthusiastic to write a narrative text. The students' writing a narrative text in the third meeting became more correctly and interpretative in writing the content and the tenses. Finally, from the explanation above, the researcher concluded that by giving teacher's feedback was an appropriate way to teach writing a narrative

text.

\section{V1. CONCLUSION}

In this study, there are two conclusions which are referred to the research questions. First, it can be concluded that teacher's written feedback helps the students write a narrative text. It is because the teacher gives the feedback clearly. It consists of how the students write the generic structures and language features of narrative texts, the tenses that the students use in their writing work, choosing the appropriate words/ diction, punctuation. It makes the students know and understand their mistakes in writing a narrative text easily. For the Second it can be concluded that most of the eighth graders students in SMP AMIRUDDIYAH could write writing narrative texts correctly after the teacher gave them teacher's written feedback. It can be seen that almost all of the students knew what they should write the orientation, complication, resolution. Although some of them still have difficulties in writing narrative texts especially in the tenses of narrative texts, the teacher's written feedback has aninfluence on the students' writing narrative texts

\section{References}

[1] Brookhart, S. (2007). Feedback that fits. Educational Leadership, 65(4), 54-59.

[2] Bogdan C, Robert and Sari Knopp B. 1992.Qualitative Research for Education. USA: Allyn and Bacon.

[3] Herrera, S. L. (2011). Exploring the Role of Corrective Feedback in Second $\quad$ Language Writing. Unpublished master's major paper.Department of Language and Education, University of British Columbia

[4] Cantony. and Harvey (1987). A Practical Guideline: An Essay to Write: New York: Hall regents.

[5] Joyce, H., \& Feez, S. (2000).Writing skills: Narrative and non-fiction text types.Sydney: Phoenix Education Pty Ltd. 